\title{
High Potential Risk of Zika Virus Infection Outbreak in Dengue Suspected Cases in Nepal
}

\author{
Yogendra Shah ${ }^{1,2, *}$, Kishor Pandey ${ }^{1,3}$, Dhan K. Pant ${ }^{2}$, Krishna P. Panta ${ }^{4}$ and Basu D. Pandey ${ }^{1,5}$ \\ ${ }^{1}$ Everest International Clinic and Research Center, Kathmandu, Nepal \\ ${ }^{2}$ National Zoonoses and Food Hygiene Research Centre, Kathmandu, Nepal \\ ${ }^{3}$ Nepal Academy of Science and Technology (NAST), Lalitpur, Nepal \\ ${ }^{4}$ Department of Microbiology, Far-Western University, Bhimduttanagar, Nepal \\ ${ }_{5}^{5}$ Sukraraj Tropical and Infectious Disease Hospital, Teku, Kathmandu, Nepal
}

\section{DEAR EDITOR,}

The viruses in the genus Flavivirus, family Flaviviridae, cause disease in humans, including dengue, yellow fever, West Nile and Zika viruses [1]. Zika virus (ZIKV) infection is considered as one of emerging international public health problems worldwide. Dengue virus (DENV) and Zika virus (ZIKV) infection are an arthropod-borne virus that transmitted to human by the bite of infected female mosquito mainly Aedes aegypti and Aedes albopiticus [2 - 4]. The same mosquitoes' species also transmit the chikungunya virus (CHIKV) and yellow fever [5]. DENV is the causative agents for Dengue Fever (DF) and of chronic cases called Dengue Hemorrhagic Fever (DHF), which may lead to Dengue Shock Syndrome (DSS) in humans. Four DENV serotypes viz DENV-1, DENV-2, DENV-3 and DENV-4 are mainly responsible for the disease [6]. According to WHO, DENV infection was reported as most emerging global public health problems with 390 million dengue infections per year globally including the Americas, South-East Asia and the Western Pacific region [7, 8]. Recently research studies revealed that ZIKA infection had similar epidemiology, transmission cycles and also same dispersal routes like DENV and CHIKV infections [9]. Till date, 85 countries has been reported laboratory verification of mosquito-borne ZIKA transmission around the world [10]. For instance, our open porous border country with three sites i.e. India has first reported three laboratory confirmed cases of ZIKV infection in May 2017 and one site border with China also documented first case in 2016 [10]. According to DENV, CHIKV and ZIKV mosquitoes are rapidly widespread throughout the tropical and subtropical developing nations strongly associated with human migration, genotypes increased

\footnotetext{
Address correspondence to this author at the Everest International Clinic and Research Center, Kathmandu, Nepal; Tel: +977-9849610127;

E-mail: yogendra90@hotmail.com
}

the virulence, influenced by climates, such as temperature/ rainfall, unplanned urbanization and also the growing global trade and travel $[5,11,12]$. ZIKV can cause infection results in microcephaly with severe brain malformations and other birth defects from pregnant women to the fetus. ZIKV also characterized similar clinical signs and symptoms with DENV and CHIKV like fever, chills, headache, vomiting, rashes, joint pain and conjunctivitis etc. [13], Therefore, there is high risk of of miss-diagnosis or under-reporting of ZIKV and CHIKV infection by the physician during the treatment of DENV in endemic areas [14].

The first DENV infection was documented in Nepal from Chitwan district in 2006 followed by sporadic reports [16]. However, DENV large outbreak has also been reported from India in 2006 affected Delhi state with at least 3613 confirmed DF and 50 deaths [14 - 16]. Nepal is open porous bordered by India in the eastern, western and southern therefore infected person may be easy across the border and possible virus might be transmitted by DENV, CHIV and ZIKV infected vector with several pieces of evidences in border districts to terai region of Nepal. All four serotypes are responsible for causing DENV infection throughout the country. There were only a few cases of DENV recognized between 2007 and 2009. In contrast, the 2010 DENV large outbreak occurred in the central and western parts of Nepal with circulating DENV-1/2 serotypes followed by DENV-2 serotypes in 2014 [ $16-19,23,24]$. Potentially, a high risk threat of ZIKV infection outbreak as already reported and established of human biting mosquito vectors i.e Aedes aegypti and Aedes Albopictus causing DENV and CHIKV infections in Nepal.

Nepal is one of vulnerable countries in South East Asian region recognized for several outbreaks reported from DENV infection in including hilly districts last 10 years' period [15 33]. In 2014, the first CHIKV infection in Nepal was 
confirmed by molecular analysis (FRNT50) [28 - 30]. Some of the South Asian countries already reported ZIKV cases, mainly Bangladesh and Myanmar in 2016, and India in 2017 [34, 35]. Nepal has open porous bordered by India in the Eastern, Western and Southern regions, therefore, DENV,CHIV and ZIKV infected person can easily cross the border from India to Nepal. Nepal being high risk for possible ZIKA outbreak due to open border with India and International travel from other countries [36]. Due to the lack of information on the diagnosis of ZIKV infection in DENV endemic regions in Nepal were unreported previously. Therefore, early differential molecular diagnosis of ZIKV from suspected DENV infections is an urgent need in Nepal. Highly specific and sensitive molecular methods are required because the high percentage of crossreactivity among the flaviviruses when serological approaches are used [37, 38].

Government of Nepal should take quick and urgent action to prevent the flavivirus infection including (DEN, ZIKV, CHIKV) by initiate surveillance mechanism integrated with vector control program to abate from an outbreak of particular flavivirus infection especially in every year monsoon season. The responsible health authorities should trace out the possible high risk of ZIKV infection hotspot region of both diseases in Nepal and neighboring countries. The government of Nepal, Ministry of Health and Population should be provide molecular testing facilities for RT-PCR and Trioplex RT-PCR in each regional hospital and also strong recommended to policymaker and planner for the further strategy to diagnosis, vector-borne control and prevention in the future outbreak of DENV and ZIKA infections throughout Nepal by applying One Health approaches.

\section{REFERENCES}

[1] Rigau-Pérez JG, Clark GG, Gubler DJ, Reiter P, Sanders EJ, Vorndam AV. Dengue and dengue haemorrhagic fever. Lancet 1998; 352(9132): 971-7.

[http://dx.doi.org/10.1016/S0140-6736(97)12483-7] [PMID: 9752834]

[2] Guzman MG, Harris E. Dengue. Lancet 2015; 385(9966): 453-65. [http://dx.doi.org/10.1016/S0140-6736(14)60572-9] [PMID: 25230594]

[3] Barcelos FL. Dengue virus 2 American-Asian Genotype identifiedduring the 2006/2007 outbreak in Piaui, Brazil reveals a Caribbean route ofintroduction and dissemination of dengue virus in Brazil (vol 9, e104516, 2014). PLoS One 2014; 9: 516.

[http://dx.doi.org/10.1371/journal.pone.0104516]

[4] Lindenbach BD, Rice CM. Flaviviridae: the viruses and their replication. In: D.M. Knipe and P.M. Howley, Fields virology, 4th edition Lippincott Williams and Wilkins, 991-1041.

[5] Hales S, de Wet N, Maindonald J, Woodward A. Potential effect of population and climate changes on global distribution of dengue fever: An empirical model. Lancet 2002; 360(9336): 830-4. [http://dx.doi.org/10.1016/S0140-6736(02)09964-6] 12243917]

[PMID:

[6] Gubler DJ. Dengue and dengue hemorrhagic fever. Clin Microbiol Rev 1998; 11(3): 480-96.

[http://dx.doi.org/10.1128/CMR.11.3.480] [PMID: 9665979]

[7] Bhatt S, Gething PW, Brady OJ, et al. The global distribution and burden of dengue. Nature 2013; 496(7446): 504-7.

[http://dx.doi.org/10.1038/nature12060] [PMID: 23563266]

[8] Dengue: Guidelines for Diagnosis, Treatment, Prevention and Control. Geneva, Switzerland: World Health Organization 2009

[9] Doss CG, Siva R, Christopher BP, Chakraborty C, Zhu H. Zika 2017: how safe is India? Infect Dis Poverty 2017; 6(1): 37.

[10] World Health Organization. Zika virus (ZIKV) classification table 2017.http://apps.who.int/iris/bitstream/10665/255767/1/zika-classificat ion-20June17-eng.pdf?ua=1
[11] Chen B, Liu Q. Dengue fever in China. Lancet 2015; 385(9978): 1621-2.

[http://dx.doi.org/10.1016/S0140-6736(15)60793-0]

[PMID: 25943817]

[12] Tambo E, Chen JH, Zhou XN, Khater EI. Outwitting dengue threat and epidemics resurgence in Asia-Pacific countries: strengthening integrated dengue surveillance, monitoring and response systems. Infect Dis Poverty 2016; 5(1): 56.

[http://dx.doi.org/10.1186/s40249-016-0148-3] [PMID: 27233238]

[13] Galan-Huerta KA, Rivas-Estilla AM, et al. The ZIKA virus disease: An overview Medicina Univeraitaria 2015; 18(71): 115-24.

[14] Carey DE. Chikungunya and dengue: a case of mistaken identity? J Hist Med Allied Sci 1971; 26(3): 243-62

[http://dx.doi.org/10.1093/jhmas/XXVI.3.243] [PMID: 4938938]

[15] WHO/SEARO. Outbreak investigation of DF in Nepal 2006.

[16] Pandey BD, Rai SK, Morita K, Kurane I. First case of Dengue virus infection in Nepal. Nepal Med Coll J 2004; 6(2): 157-9.

[PMID: 16295753]

[17] Takasaki T, Kotaki A, Nishimura K, et al. Dengue virus type 2 isolated from an imported dengue patient in Japan: First isolation of dengue virus from Nepal. J Travel Med 2008; 15(1): 46-9. [http://dx.doi.org/10.1111/j.1708-8305.2007.00165.x] 18217869]

[18] Malla S, Thakur GD, Shrestha SK, et al. Identification of all dengue serotypes in Nepal. Emerg Infect Dis 2008; 14(10): 1669-70. [http://dx.doi.org/10.3201/eid1410.080432] [PMID: 18826846]

[19] Pandey BD, Nabeshima T, Pandey K, et al. First isolation of dengue virus from the 2010 epidemic in Nepal. Trop Med Health 2013; 41(3): 103-11.

[http://dx.doi.org/10.2149/tmh.2012-17] [PMID: 24155651]

[20] WHO

2011.http://www.searo.who.int/LinkFiles/Dengue_Dengue_update_SE A_2010.pdf

[21] Pun SB. Dengue: an emerging disease in Nepal. JNMA J Nepal Med Assoc 2011; 51(184): 203-8.

[http://dx.doi.org/10.31729/jnma.33] [PMID: 22922903]

[22] Pandey BD, Morita K, Khanal SR, et al. Dengue virus, Nepal. Emerg Infect Dis 2008; 14(3): 514-5

[http://dx.doi.org/10.3201/eid1403.070473] [PMID: 18325280]

[23] Dumre SP, Shakya G, Na-Bangchang K, et al. Dengue virus and Japanese encephalitis virus epidemiological shifts in Nepal: a case of opposing trends. Am J Trop Med Hyg 2013; 88(4): 677-80. [http://dx.doi.org/10.4269/ajtmh.12-0436] [PMID: 23419366]

[24] Singh S, Gupta BP, Manakkadan A, Das Manandhar K, Sreekumar E. Phylogenetic study reveals co-circulation of Asian II and Cosmopolitan genotypes of Dengue virus serotype 2 in Nepal during 2013. Infect Genet Evol 2015; 34: 402-9.

[http://dx.doi.org/10.1016/j.meegid.2015.07.006] [PMID: 26160542]

[25] Gupta BP, Singh S, Kurmi R, Malla R, Sreekumar E, Manandhar KD. Re-emergence of dengue virus serotype 2 strains in the 2013 outbreak in Nepal. Indian J Med Res 2015; 142(7)(Suppl.): S1-6. [http://dx.doi.org/10.4103/0971-5916.176564] [PMID: 26905233]

[26] Epidemiology of Diseases Control Division. EWARS weekly bulletin Ministry of Health, Department of Health Services Kathmandu.

[27] Dumre SP, Bhandari R, Shakya G, et al. Dengue virus serotypes 1 and 2 responsible for major dengue outbreaks in nepal: Clinical, laboratory, and epidemiological features. Am J Trop Med Hyg 2017; 97(4): 1062-9.

[http://dx.doi.org/10.4269/ajtmh.17-0221] [PMID: 29031282]

[28] Pun SB, Bastola A, Shah R. Case report: first report of chikungunya virus in Nepal. J Infect Dev Ctries 2014; 8: 790-2. [http://dx.doi.org/10.3855/jidc.3701] [PMID: 24916880]

[29] Pandey BD, Neupane B, Pandey K, Tun MM, Morita K. Detection of Chikungunya virus in Nepal. Am J Trop Med Hyg 2015; 93(4): 697-700.

[http://dx.doi.org/10.4269/ajtmh.15-0092] [PMID: 26195462]

[30] Pandey K, Pandey BD, Chaurasiya RR, et al. Evidence of Chikungunya virus circulation in the Terai region of Nepal in 2014 and 2015. Trans R Soc Trop Med Hyg 2017; 111(7): 294-9.

[http://dx.doi.org/10.1093/trstmh/trx059] [PMID: 29165625]

[31] Pandey BD, Pandey K, Neupane B, et al. Persistent dengue emergence: The 7 years surrounding the 2010 epidemic in Nepal. Trans R Soc Trop Med Hyg 2015; 109(12): 775-82.

[http://dx.doi.org/10.1093/trstmh/trv087] [PMID: 26507529]

[32] Shah Y, Katuwal A, Pun R, et al. Dengue in western Terai region of Nepal. J Nepal Health Res Counc 2012; 10(21): 152-5. [PMID: 23034379] 
[33] Poudel A, Shah Y, Khatri B, Joshi DR, Bhatta DR, Pandey BD. The burden of dengue infection in some vulnerable regions of Nepal. Nepal Med Coll J 2012; 14(2): 114-7.

[PMID: 23671960]

[34] Reuters Bangladesh confirms first case of Zika virus 2016. http://ww w.reuters.com/article/us-health-zika-bangladesh-idUSKCN0WO0VJ

[35] World Health Organization. Emergencies preparedness, response: Zika virus infection - India 2017.http://www.who.int/csr/don/26-may2017-zika-ind/en/

[36] Dhimal M, Dahal S, Dhimal ML, et al. Threats of Zika virus trans- mission for Asia and its Hindu-Kush Himalayan region. Infect Dis Poverty 2018; 7(1): 40.

[http://dx.doi.org/10.1186/s40249-018-0426-3]

[37] Balmaseda A, Stettler K, Medialdea-Carrera R, Collado D, Jin X, Zambrana JV. Antibody based assay discriminates Zika virus infection from other flaviviruses. Proc Natl Acad Sci U S A 2017; 1;114(31): 8384-9.

[http://dx.doi.org/10.1073/pnas.1704984114]

[38] World Health Organization. Dengue hemorrhagic fever: diagnosis, treatment and control 1997.

\section{(C) 2019 Shah et al.}

This is an open access article distributed under the terms of the Creative Commons Attribution 4.0 International Public License (CC-BY 4.0), a copy of which is available at: (https://creativecommons.org/licenses/by/4.0/legalcode). This license permits unrestricted use, distribution, and reproduction in any medium, provided the original author and source are credited. 